\title{
Occupational health hazards and use of personal protective equipment among automobile mechanics in Surulere local government area of Lagos State, Nigeria - a descriptive study
}

\author{
Ozomata EA ${ }^{1}$, Osagiede $\mathrm{EF}^{2}$, Onyebujoh $\mathrm{TJ}^{2}$
}

${ }^{1}$ Department of Community Health, Lagos University Teaching Hospital, Idi-Araba, Lagos, Nigeria, ${ }^{2}$ Department of Community Medicine, Irrua Specialist Teaching Hospital, Irrua, Nigeria

\section{ABSTRACT}

Introduction: The job of an automobile mechanic is associated with hazards, illness, and injuries, which may result in sickness, absenteeism, economic loss, disability, or even death. This study assessed the level of knowledge and workplace safety practice by automobile mechanics.

Methods: A descriptive cross-sectional study was carried out among 120 registered automobile mechanics in Surulere Local Government Area of Lagos State, Nigeria. A questionnaire was used to obtain information on sociodemography and occupational health practices. Data entry and analysis were done with Epi-info 3.5.1(2008). Chisquare and Fischer Exact tests were used to test for significance.

Results: The respondents were all males with a mean age of $39.9 \pm 7.5$ years, the majority learned the trade through apprenticeship (95.80\%) and on full-time work (98.30\%). Most respondents (95.8\%) were aware of at least one health problem associated with its hazards. Over $75 \%$ of respondents were aware of physical hazards. Over eighty percent $(84.17 \%)$ of respondents used their own overalls, $40 \%$ of them used overalls regularly, and only $26.67 \%$ of respondents used overalls appropriately.

Conclusion: Many respondents were aware of health problems, occupational hazards, and PPE used in the Automobile workplace but did not translate to good practice of workplace safety as seen in only $1.67 \%$. The respondents did not deem the use of PPE necessary and lack, or inadequate training on the 'how' and 'why' PPE were identified as factors hindering PPE use. Workers' training and adherence monitoring could help improve good workplace safety practices in Lagos, Nigeria.

Key words: Automobile mechanics, Health hazards, Occupational, Personal protective equipment, Surulere Lagos.

\section{INTRODUCTION}

G lobally, the protection of workers against workrelated injuries and illnesses over the years has been an issue of concern. This is because a safe work

DOI: https://doi.org/10.3126/ijosh.v12i1.41035

Conflicts of interest: None

Supporting agencies: None

Date of submission: 14.06.2021

Date of acceptance: 24.09.2021

Date of publication: 01.01.2022

\section{Corresponding Author}

Dr. Emmanuel Friday Osagiede,

Consultant Public Health Physician,

Department of Community Medicine,

Irrua Specialist Teaching Hospital, Irrua, Nigeria.

E-mail: drosagiedeef@gmail.com

ORCID: https://orcid.org/0000-0001-5254-6783 environment promotes workers' physical, mental, and social wellbeing and saves costs associated with medical bills, work interruption, loss of experienced personnel, compensation, and others resulting from accidents at the workplace. ${ }^{1}$ Automobile mechanics are workers who repair and overhaul cars and other automotive vehicles or their systems and parts. ${ }^{1}$ The automobile mechanics are exposed to a variety of occupational hazards with detrimental health effects or injuries. ${ }^{2}$ These hazards, like as experienced by other workers, could be ergonomic, physical, chemical, biological and/or psychosocial. ${ }^{3}$ Generally, occupational hazards are described as those factors in the work environment, which can lead to injury or

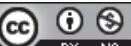

This journal is licensed under a Creative Commons AttributionNon Commercial 4.0 International License. 
adverse health conditions (disease). ${ }^{4}$ In other words, they are the risks or dangers that an individual is exposed to at the workplace.

Ergonomic hazards from awkward posture, repetitive motion and poorly designed workstations could lead to acute musculoskeletal injuries, intervertebral disc rupture, tendon rupture, hernia, or cumulative trauma disorders including carpal tunnel syndrome. Physical agents pose physical hazards and are capable of affecting the biological mechanism of exposed workers. ${ }^{4}$ Examples of physical hazards include radiation, noise, temperature, pressure, vibration, and light. In the automobile mechanic's workshop, hand-arm vibration from power-driven hand tools can lead to white finger syndrome. ${ }^{4}$ Chemical hazards are posed by chemical substances used in industries which can be organic or inorganic in chemical composition and liquid, dust, fume vapor, mist, or gas formulations. ${ }^{4}$ These are a wide range of industrial chemicals such as heavy metals contained in brake fluids, degreasers, detergents, lubricants, metal cleaners, paints, fuel, and solvents resulting in lead poisoning, skin diseases, irritation of the eyes and mucous membranes and cancers. ${ }^{3}$ Psychosocial hazards are related to the organization in the workplace, including the worker's relationship with his fellow workers or with the management. ${ }^{3}$ This has a lot of influence on the individual's morale, job satisfaction, general wellbeing, and health. These hazards, depending on the magnitude and duration of exposure, or the individual worker's capacity to adapt, may result in various psychological or emotional disorders or negative behavior and attitude to work. ${ }^{4}$ Biological hazards are those posed by living organisms leading to acute or chronic infection, usually viral, bacterial, or fungal origin or parasitic infection or infestation in the workplace.

Personal protective equipment (PPE) minimizes exposure to a variety of hazards. ${ }^{5}$ Active cooperation and compliance of the workers are necessary for maximum benefits derived from PPE utilization. ${ }^{6}$ Personal protective equipment includes gloves, overalls, helmets, boots, earmuffs, and goggles. ${ }^{5}$ The automobile occupation is associated with hazards that could result in injuries, illness, or fatality. Globally, 160 million new cases and about 1.1 million deaths are associated with work-related diseases and injuries. ${ }^{7}$

In Nigeria, automobile mechanics are either selfemployed or belong to a small-scale industry where the occupational health problems of workers are not documented. As a result, health services are not readily available to meet their health, welfare, and safety needs. Researchers alike have not shown much interest in this area. This study aimed to describe the magnitude of the health hazards faced by these sets of workers and their use of PPE while at work.

\section{METHODS}

This descriptive cross-sectional study was carried out in Surulere Local Government Area (LGA) of Lagos State, Nigeria. One of twenty LGAs of Lagos State. Surulere is both residential and commercial, spanning $23 \mathrm{~km}^{2}$. There were 503,975 inhabitants, with a population density of 21,864 inhabitants per $\mathrm{km}^{2}$ as at the time of the 2006 census. $^{8}$

All cadres of automobile mechanics were included in the study. The mechanics are organized under the Nigerian Automobile Technician Association (NATA). NATA is under the Ministry of Labor and Productivity. These workers have no organized occupational health service that offers preventive and curative services. Surulere LGA has three major mechanic villages: Babs Animashaun, Randle, and Canal, and fourteen minor mechanic workshops. In general, the LGA has a total of 45 registered automobile mechanic workshops, with the number of workers in each workshop varying from 1 to 17 . In total, there were 254 registered automobile mechanics in the LGA during this study. A total of 120 consenting registered automobile mechanics were selected and interviewed using a systematic sampling technique.

Data were collected from respondents in the selected workshops with the help of two research assistants. Data collection was done with the aid of an interviewer-administered questionnaire designed by the researchers. The instrument was pretested and validated among twenty-four automobile mechanics working at the Mushin LGA, Lagos State, Nigeria.

Information obtained includes socio-demographic characteristics of the study population, their occupation and occupational health history, and their knowledge and practice regarding occupational hazards and safety measures. Data entry and analysis were subsequently done using epi-info 3.5.1(2008). Chisquare and Fischer tests were used to test for significance. Significant association ( $p$-value < 0.05) was determined. 


\section{RESULTS}

Table 1 shows the sociodemographic characteristics of the study respondents.

About $95 \%$ of the respondents were aged at least 30 years, and $53 \%$ were between 35 and 44 years. Their mean age was $39.9( \pm 7.5)$ years. Sixty percent of the respondents attained a primary level of formal education, and only $4(3.3 \%)$ of the respondents had tertiary education. The majority, $106(88.33 \%)$ earn a daily income of less than $\$ 5,000.00$ (\$14) per day with

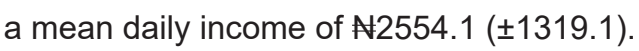

Almost all the respondents were on full-time work and had their training through an apprenticeship. A high proportion of the respondents $(70.8 \%)$ were putting in over eight hours of work time daily. Their mean duration of training and work experience was $6.5( \pm 2.2)$ years and $14.3( \pm 7.4)$ respectively.

Almost all the respondents (95.83\%) were aware of the work-related health problems of the automobile workers. Ninety-three $(77.50 \%)$ of respondents knew they could suffer burns from some of the hazards they are exposed to at work. Sixty-five (54.17\%) respondents linked burns to exposure to hot metal surfaces, amongst other causes including fire outbreak from petrol explosion [37 (30.83\%)], the opening of the radiator [23 (19.17\%)], electrocution [16 (13.33\%)], and hot machine oil [1 $(0.83 \%)]$ in multiple responses. 104 $(67 \%)$ of respondents knew they could suffer cuts at the workplace resulting from contact with sharp edges of hand tools as reported by $88(73.33 \%)$ respondents and from sharp edges of motor parts as reported by $13.33 \%$ of the respondents.

Thirty-one (25.83\%) respondents knew that musculoskeletal injuries were associated with their work, $58(48.33 \%)$ of respondents knew that chemical poisoning could result from the sucking of petrol and ingestion of machine oil, and $45(37.50 \%)$ respondents knew they could be psychologically stressed from pressures at the workplace.

Most of the respondents $(96.67 \%)$ were aware of safety devices, $110(91.67 \%)$ knew that overalls are safety devices, $86.67 \%$ knew that boots are safety devices, and $74.17 \%$ knew rubber gloves as safety devices. Eighty-nine (74.17\%) and 60 (50.00\%) respondents respectively learned about these devices and equipment from training during the apprenticeship and their co-workers.

Generally, the majority $(84.17 \%)$ of the respondents used overalls but only $40 \%$ of them used it always. Over seventy-two percent (87) of respondents had boots, however, only one-third (33.33\%) used their boots always. Only $2.50 \%$ had helmets and they only used them occasionally.

Most respondents who did not have PPE believed they were not necessary. This applied to goggles, facemasks, overalls, gloves, boots, earmuffs, barrier cream, and helmets.

Of the $100(83.33 \%)$ respondents that wore overalls, only $32(26.67 \%)$ wore them appropriately. None of those having goggles [4, (3.33\%)] correctly applied it (Table 8).

Older age, higher daily income (>5,000 nairas), learning of skills through apprenticeship (compared to formal school), and the longer duration of training (>6 years) seems to be associated with good safety practices, there was generally no statistically significant relationship between respondents' socio-demographic characteristics (Table 9). In general, only $1.66 \%$ of respondents had good safety practices. A majority $(79.17 \%)$ had poor safety practices.

A majority $(79.17 \%)$ of the respondents had poor safety practices. Only two (1.6\%) of them had good work safety practices.

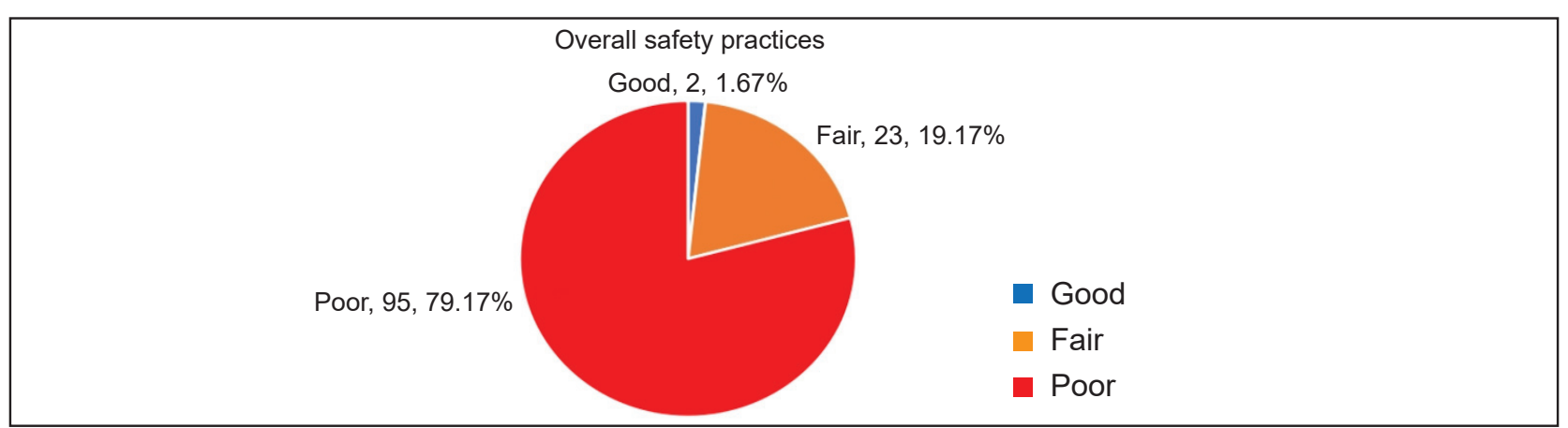

Figure 1: Overall workplace safety practices. 
Table 1: Sociodemographic characteristics of respondents

\begin{tabular}{|c|c|c|}
\hline Variable & Frequency $(\mathrm{N}=120)$ & Percentage (\%) \\
\hline \multicolumn{3}{|l|}{ Age group (years) } \\
\hline$<25$ & 1 & 0.83 \\
\hline $25-29$ & 7 & 5.83 \\
\hline $30-34$ & 17 & 14.17 \\
\hline $35-39$ & 39 & 32.50 \\
\hline $40-44$ & 25 & 20.83 \\
\hline$\geq 45$ & 31 & 25.84 \\
\hline \multicolumn{3}{|l|}{ Mean $\pm S D=39.9 \pm 7.5$} \\
\hline \multicolumn{3}{|l|}{ Marital status } \\
\hline Single & 8 & 6.7 \\
\hline Married & 112 & 93.3 \\
\hline \multicolumn{3}{|l|}{ Educational status } \\
\hline No formal education & 7 & 5.83 \\
\hline Primary education & 72 & 60 \\
\hline Secondary education & 37 & 30.83 \\
\hline Tertiary education & 4 & 3.34 \\
\hline \multicolumn{3}{|l|}{ Religion } \\
\hline Christianity & 51 & 42.5 \\
\hline Islam & 69 & 57.5 \\
\hline \multicolumn{3}{|l|}{ Ethnicity } \\
\hline Yoruba & 115 & 95.83 \\
\hline Igbo & 4 & 3.33 \\
\hline Edo & 1 & 0.84 \\
\hline \multicolumn{3}{|l|}{ Estimated daily income (Naira) } \\
\hline$<2500$ & 66 & 55.00 \\
\hline $2500-4999$ & 40 & 33.33 \\
\hline$\geq 5000$ & 14 & 11.67 \\
\hline Mean $\pm S D=2554.1 \pm 1319.1$ & & \\
\hline
\end{tabular}

Table 2: Work-related characteristics of the respondents.

\begin{tabular}{|c|c|c|}
\hline Variable & Frequency $(\mathrm{N}=120)$ & Percentage (\%) \\
\hline \multicolumn{3}{|l|}{ Nature of job } \\
\hline Full time & 118 & 98.30 \\
\hline Part-time & 2 & 1.70 \\
\hline \multicolumn{3}{|l|}{ Mode of training } \\
\hline Apprenticeship & 115 & 95.80 \\
\hline Formal mechanic school & 5 & 4.20 \\
\hline \multicolumn{3}{|c|}{ Duration of training (years) } \\
\hline$<6$ & 65 & 54.20 \\
\hline$\geq 6$ & 55 & 45.80 \\
\hline \multicolumn{3}{|l|}{ Mean $\pm S D=6.5 \pm 2.2$} \\
\hline \multicolumn{3}{|l|}{ Work experience (years) } \\
\hline$<4$ & 9 & 7.50 \\
\hline $5-9$ & 24 & 20.00 \\
\hline $10-14$ & 28 & 23.33 \\
\hline $15-19$ & 26 & 21.67 \\
\hline 20 and above & 33 & 27.50 \\
\hline Mean $\pm S D=14.3 \pm 7.4$ & & \\
\hline
\end{tabular}


Table 3: Awareness and knowledge of respondents of health hazards and associated health problems.

\begin{tabular}{lcc}
\hline Variable & Frequency (N =120) & Percentage (\%) \\
\hline Awareness of work-related health problems & 115 & 95.83 \\
Yes & & 77.50 \\
Health hazards with associated health problems & 93 & 54.17 \\
\hline Burns & 65 & 19.17 \\
Burns from hot metal surface & 23 & 30.83 \\
Burns from the opening of the radiator & 37 & 13.33 \\
\hline Burns from petrol explosion and fire outbreak & 16 & 0.83 \\
Burns from electrocution & 1 & 86.67 \\
\hline Burns from hot machine oil & 104 & 73.33 \\
Cuts & 88 & 13.33 \\
\hline Sharp edges of hand tools & 16 & 17.50 \\
\hline Sharp edges of motor parts & 21 & 35.00 \\
\hline Road traffic accident from test driving & 42 & 10.00 \\
\hline Eye injury from flying objects & 12 & 40.83 \\
\hline Fracture from fall of heavy objects & 49 & \\
\hline Crushed finger/ toes from moving machine parts & & \\
\hline
\end{tabular}

\$Multiple responses were applicable.

Table 4: Knowledge of work-related health problems

\begin{tabular}{lcc}
\hline Variable & Frequency (N=120) & Percentage (\%) \\
\hline Work-related health problems & & 2.50 \\
Hand dermatitis from brake oil & 3 & 22.50 \\
Tetanus from untreated wound(s) & 27 & 17.50 \\
Vector-borne diseases & 21 & 48.33 \\
Chemical poisoning & 58 & 44.17 \\
Ingestion of petrol (from mouth sipping). & 53 & 4.17 \\
Ingestion of machine oil & 5 & 25.83 \\
Musculoskeletal diseases & 31 & 25.00 \\
Injuries from lifting heavy vehicle parts & 30 & 5.00 \\
Working in an awkward position & 6 & 37.50 \\
Psychological stress & 45 & 35.00 \\
Verbal abuse & 42 & 1.67 \\
\hline Physical assault & 2 & \\
\hline
\end{tabular}

\$Multiple responses applicable

Table 5: Respondents' knowledge of automobile workplace safety devices.

\begin{tabular}{lcc}
\hline Variable & Frequency $(\mathbf{N = 1 2 0 )}$ & Percentage (\%) \\
\hline Awareness of safety devices & & 96.67 \\
Yes & 116 & 50.00 \\
Sources of knowledge of safety devices & & 1.67 \\
Co-worker & 60 & 0.83 \\
TV/Radio & 2 & 5.00 \\
Clinic/Hospital & 1 & 24.17 \\
Books/Magazines & 6 & 1.67 \\
Special safety training & 29 & 74.17 \\
Daily meetings & 2 & 89 \\
Apprenticeship & 2 &
\end{tabular}


Knowledge of safety devices ${ }^{\S}$

\begin{tabular}{lcc} 
Facemask & 54 & 45.00 \\
Rubber glove & 89 & 74.17 \\
Earmuffs & 3 & 2.50 \\
Boots & 104 & 86.67 \\
Barrier cream & 2 & 1.67 \\
Googles & 59 & 49.17 \\
Helmet & 42 & 35.00 \\
\hline
\end{tabular}

$\S$ Multiple responses were applicable.

Table 6: Frequency of use of PPE among respondents.

\begin{tabular}{lccc}
\hline \multirow{2}{*}{ PPE (Number of respondents who have) } & \multicolumn{3}{c}{ Frequency of Use } \\
\cline { 2 - 4 } Boots $(n=87)$ & Always (\%) & Most times (\%) & Occasionally (\%) \\
Gloves $(n=54)$ & $40(33.33)$ & $27(22.50)$ & $20(16.67)$ \\
Facemask $(n=22)$ & $16(13.33)$ & $23(19.17)$ & $15(12.50)$ \\
Goggles $(n=18)$ & $6(5.00)$ & $6(5.00)$ & $10(8.33)$ \\
Helmets $(n=3)$ & $8(6.67)$ & $6(5.00)$ & $4(3.33)$ \\
\hline
\end{tabular}

Table 7: Reasons why respondents did not possess PPE.

\begin{tabular}{lccccc}
\hline $\begin{array}{l}\text { PPE (Number of } \\
\text { respondents who do } \\
\text { not have) }\end{array}$ & $\begin{array}{c}\text { It is expensive. } \\
\text { (\%) }\end{array}$ & $\begin{array}{c}\text { Do not know if } \\
\text { it exists. (\%) }\end{array}$ & $\begin{array}{c}\text { Not trained on } \\
\text { the use. (\%) }\end{array}$ & $\begin{array}{c}\text { Not necessary } \\
(\%)\end{array}$ & $\begin{array}{c}\text { It causes } \\
\text { discomfort (\%) }\end{array}$ \\
\hline Goggles $(n=102)$ & $0(0.00)$ & $0(0.00)$ & $4(3.33)$ & $82(68.33)$ & $16(13.33)$ \\
\hline Facemask $(n=98)$ & $2(1.67)$ & $1(0.83)$ & $4(3.33)$ & $75(62.50)$ & $16(13.33)$ \\
Gloves $(n=67)$ & $0(0.00)$ & $0(0.00)$ & $1(0.83)$ & $53(44.17)$ & $13(10.83)$ \\
Boots $(n=33)$ & $2(1.67)$ & $0(0.00)$ & $2(1.67)$ & $20(16.67)$ & $9(7.50)$ \\
Earmuffs $(N=120)$ & $3(2.50)$ & $2(1.67)$ & $3(2.50)$ & $99(82.50)$ & $13(10.83)$ \\
Cream $(\mathrm{N}=120)$ & $3(2.50)$ & $2(1.67)$ & $3(2.50)$ & $98(81.67)$ & $14(11.67)$ \\
Helmet $(n=117)$ & $4(3.33)$ & $3(2.50)$ & $2(1.67)$ & $94(78.33)$ & $14(11.67)$ \\
\hline
\end{tabular}

Table 8: Appropriate use of PPE by respondents.

\begin{tabular}{lcc}
\hline \multirow{2}{*}{ PPE (Number in use) } & \multicolumn{2}{c}{ Use of PPE } \\
\cline { 2 - 3 } & Appropriate (\%) & Inappropriate (\%) \\
\hline Goggles $(n=4)$ & $0(0.00)$ & $4(3.33)$ \\
Facemasks $(n=12)$ & $7(5.83)$ & $42(4.17)$ \\
Rubber boots $(n=61)$ & $19(15.83)$ & $5(4.17)$ \\
Hand gloves $(n=6)$ & $1(0.83)$ & \\
\hline
\end{tabular}

Table 9: Association between socio-demographic/work-related characteristics and safety practices of respondents.

\begin{tabular}{|c|c|c|c|c|c|}
\hline \multirow{2}{*}{ Variable } & \multicolumn{3}{|c|}{ Practice } & \multirow[t]{2}{*}{$x^{2}$} & \multirow[t]{2}{*}{ P-value } \\
\hline & Poor (\%) & Fair (\%) & Good (\%) & & \\
\hline \multicolumn{6}{|c|}{ Age group (years) } \\
\hline$<35$ & $12(48.00)$ & $7(28.00)$ & $6(24.00)$ & 3.229 & 0.520 \\
\hline $35-44$ & $22(34.38)$ & $30(46.88)$ & $12(18.75)$ & & \\
\hline$>44$ & $10(32.26)$ & $13(41.94)$ & $8(25.81)$ & & \\
\hline \multicolumn{6}{|c|}{ Daily income (Naira) } \\
\hline$<2500$ & $27(40.91)$ & $27(40.91)$ & $12(18.18)$ & 2.656 & $0.628^{* *}$ \\
\hline $2500-4999$ & $13(32.50)$ & $18(45.00)$ & $9(22.50)$ & & \\
\hline$\geq 5000$ & $4(28.57)$ & $5(35.71)$ & $5(35,71)$ & & \\
\hline
\end{tabular}




\begin{tabular}{lccccc} 
Educational level & & & & \\
No formal education & $3(42.86)$ & $4(57.14)$ & $0(0.00)$ & 5.491 & $0.605^{* *}$ \\
\hline Primary & $25(34.72)$ & $31(43.05)$ & $16(22.22)$ & & \\
Secondary & $13(35.14)$ & $14(37.84)$ & $10(27.03)$ & & \\
Tertiary & $3(75.00)$ & $1(25.00)$ & $0(0.00)$ & & \\
Mode of training & & & & & \\
\hline Apprenticeship & $42(36.52)$ & $48(41.74)$ & $25(21.74)$ & 0.026 & $1.00^{* *}$ \\
\hline Formal Mechanic school & $2(40.00)$ & $2(40.00)$ & $1(20.00)$ & & \\
Training duration(years) & & & & & \\
$0-6$ & $26(40.00)$ & $26(40.00)$ & $13(20.00)$ & 0.706 & 0.703 \\
\hline$>6$ & $18(32.73)$ & $24(43.64)$ & $13(23.64)$ & & \\
Work experience (years) & & & & & \\
$0-4$ & $4(44.44)$ & $1(11.11)$ & $4(44.44)$ & 7.984 & $0.430^{* *}$ \\
\hline $5-9$ & $9(37.50)$ & $12(50.00)$ & $3(12.5)$ & & \\
$10-14$ & $11(39.29)$ & $9(32.14)$ & $8(28.57)$ & & \\
$15-19$ & $8(30.77)$ & $13(50.00)$ & $5(19.23)$ & & \\
$\geq 20$ & $12(36.36)$ & $15(45.45)$ & $6(18.18)$ & & \\
\hline
\end{tabular}

${ }^{* *}$ Fisher $p$-value

\section{DISCUSSION}

In this study, the mean age of the respondents was 39.9 +7.5 years. The respondents were grossly uneducated, with the highest level of completed education being primary. Most of the respondents were into their jobs on a full-time basis and were engine mechanics and spray painters. These characteristics were similar to findings from other studies carried out in some other parts of Nigeria. ${ }^{10,11}$ However, in more recent studies in the same regions, it was revealed that the attained educational level for most of the respondents was secondary. ${ }^{12,13}$ Most of the respondents in this study acquired their automobile skills through apprenticeship. This finding was similar to findings from other previous studies in Nigeria. ${ }^{5,11}$ This method of learning artisanship, as seen in this study, is not surprising because learning this occupation in developing countries like Nigeria is usually done through apprenticeship since the formal schools (technical) for learning them are not readily available. Moreover, it is easier to learn this trade as it requires no payment of school fees on regular basis as against what is obtainable in the formal school settings.

In this study, over $95 \%$ of respondents were aware of at least one health problem associated with exposure to hazards at the workplace and at least one form of safety measure. This is corroborated by evidence provided by another study carried out in the South region of Nigeria, where all respondents were aware of at least one health hazard associated with their occupation. ${ }^{5}$ Similar findings were seen from the study carried out in eastern Nepal and Southern India amongst welders where most of the respondents $90.70 \%$ and $83.30 \%$ respectively were aware of at least one health hazard of welding. ${ }^{14,15}$ These workers usually get their information about these occupational health problems along with the skill acquisition process. In other cases, they get to know from near-miss incidents, lessons from their colleagues, masters, and for a few from schools.

In this study, over three-quarters of respondents were aware of physical hazards such as heat from hot surfaces, fire explosion from petrol, the opening of a hot radiator, and electrocution, all resulting in burns. Similarly, the study carried out in Eastern Nepal reported supporting findings with a majority (90.70\%) of respondents reporting excessive brightness, $(83.70 \%)$ indicated heat, and $(17.00 \%)$ reported vibration as a form of physical hazards. ${ }^{14} \mathrm{~A}$ high level of awareness (99.4\%) of ocular hazards associated with welding activities was also reported in a study carried out amongst commercial welders' in Enugu State, Nigeria. ${ }^{16}$ About a quarter of the respondents in this study knew that musculoskeletal injuries were associated with their work. This is like the findings from the United States, where over one-third of automobile mechanics commonly present with sprains and strains. ${ }^{17}$ This may be due to the practice of manual 
lifting of the heavy object as identified by a quarter of the respondents in this study who matched lifting of heavy vehicular parts to musculoskeletal disease. In the U.S. study, it was revealed that sprains were followed by cuts, lacerations, and punctures (15.90\%), which were higher than the rate $(9.60 \%)$ for all other occupations. ${ }^{17}$ However, a higher proportion was reported in the study carried out in Northern Nigeria and Southern India where at least one-half of the workers were reported to have musculoskeletal injuries. ${ }^{9,10,15}$ In the Northern Nigeria study, fifty-four percent of the respondents had low back pain. ${ }^{10}$ Over eighty-six percent of respondents in this study knew they could suffer cuts at the workplace resulting from contact with sharp edges of hand tools and motor parts. This is like findings in an Eastern Nigerian study in which $84.10 \%$ of respondents experienced cuts at the workplace. ${ }^{18}$ Similarly, a study carried out in an urban area in Ghana among vehicle repair artisans comprising of auto-mechanics, electricians, welders, sprayers, and automobile interior designers revealed that a high proportion (64\%) of the artisans had workrelated injuries mostly from cuts and burns. ${ }^{19}$ Highest percentage(82\%) of physical injuries were reported among auto-mechanics compared to other artisans which corroborated the Eastern Nigerian study and the result of this study. ${ }^{18,19}$

In this study, almost all the respondents were aware of at least one type of safety device used by the automobile workers. Most of them knew of overalls, boots, and rubber gloves as PPEs. About three-quarters and onehalf of the respondents learned about this equipment from training during the apprenticeship and from their co-workers, respectively. This finding was similar to the finding from a study carried out among welders in Jos metropolis, in which most respondents reported using at least one item of PPE. ${ }^{20}$ In this study, a majority $(84.17 \%)$ of the respondents used overalls in one form or the other, with forty percent reporting regular use. This may be because these artisans commonly wear clothing that is different from the one, they came with from home to keep their home wears free from workshop dirt. This finding was consistent with findings from previous research done by Aiyenigba in Lagos, in which overalls were the most (93.6\%) known PPE. ${ }^{21}$ Contrary to the foregoing, is the finding from a study carried out among automobile mechanics in Nepal, where only $49.3 \%$ were found to have used protective clothing. ${ }^{22}$ The act of just wearing overall without a deep knowledge of the possible reason for wearing them could be responsible for the report in this study where only $26.67 \%$ wore their overalls appropriately.

Another commonly used PPEs in this survey was safety boots worn by over seventy percent of respondents. This finding was slightly higher than the findings from the study carried in Nepal, where $61.4 \%$ of the respondents used safety shoes but far higher than as reported among welders in Edo State, SouthSouth region of Nigeria where safety boots were worn by just about $24.1 \%$ of the respondents. ${ }^{5,22}$ However, in this study, it was revealed that only one-third of the respondents in this study used their safety boots always.

The least frequently used PPEs were helmets $(2.50 \%)$ and goggles (15.83\%), and both were abysmally lower than findings from other previous studies among welders and auto-mechanics alike.,22 This abysmally low usage of helmets and goggles was not surprising as most respondents who did not have these PPE believed they were not necessary. Other PPE in this category of least frequently used in this study were facemasks, gloves, earmuffs, and barrier cream. More disturbing was the fact that the few that were using PPE applied them inappropriately. Overall, less than two percent of respondents had good safety practices in this study while almost four-fifth of the respondents had poor safety practices.

The association between socio-demographic characteristics and safety practices by the automobile mechanics revealed that older age, higher daily income ( $>5,000$ nairas), learning of skills through apprenticeship (compared to formal school), and the longer duration of training ( $>6$ years) seems to be associated with good safety practices. Although, there was generally no statistically significant relationship between respondents' socio-demographic characteristics and their occupational history safety practices. The fact that older age and higher daily income ( $>5,000$ nairas) seems to be associated with good workplace safety practices may be because the older automobile mechanics would have been in the trade for a long time, they are likely to be masters, with more experience on the job and may have more money to buy these PPE, hence, the seemly associated good practices. This finding was relatively corroborated with the finding from the study on the factors influencing the use of PPE by motor vehicle repair workers in Kigandaini Thika, Kenya, where it was revealed that 
older age, more educated, more experienced workers in the higher income bracket, as well as those with a previous injury experience, are more likely to use PPE. ${ }^{22}$

\section{CONCLUSION}

The automobile mechanic trade is commonly learned through apprenticeship. Most of the respondents were aware of the automobile mechanics' health problems and safety devices, with higher proportions knowing about overalls (clothing) and safety boots. However, this did not translate to good practice, as only a few of them were found to always use their PPEs, and many among these were found not to have applied these PPE appropriately. The obvious poor workplace safety practice was because the respondents deemed it unnecessary to use their safety devices while at work in some cases where they were available.

\section{REFERENCES}

1. Israel Institute for Occupational Safety and Hygiene jointly with the BIA (Germany). International Hazard Datasheets on Occupation. In: ILO/CIS. 1999. p. 1-4. Available from: https://www.ilo.org/safework/ info/publications/WCMS_113135/lang--en/index.htm

2. International Labour Organization. Safety in numbers. 1st ed. Vol. 21, Concrete Producer. Geneva: ILO; 2003. 1-33 p. Available from: https://www.ilo.org/ wcmsp5/groups/public/---europe/---ro-geneva/--sro-moscow/documents/genericdocument/ wcms_305841.pdf

3. International Labour Organization /Centre International d'informations de Securite et de Sante au Travail. International Hazard Datasheets on Occupation Mechanic, automobile. Geneva; 2000. p. 1-4. Available from: https://www.lo.org/safework/cis/ WCMS_193167/lang--en/index.htm

4. Obionu CN. Synopsis of Occupational and Environmental Health. Uwani-Enugu. Cedartop(nig.) press Itd. 1999. 1-20 p.

5. Osagiede EF, llokhor O k., Ehimen FA, Airefetalor IA, Otaigbe OI, Abah SO. Assessment of Awareness of Occupational Health Problems, and the Practices of Safety Measures among Welders in a Semi-Urban Town in South-South Nigeria. West J Med \& Biomed Sciest J Med \& Biomed Sci. 2020;1(2):139-49.

6. Johnson O, Motilewa O. Knowledge and Use of Personal Protective Equipment among Auto Technicians in Uyo, Nigeria. Br J Educ Soc Behav Sci. 2016;15(1):1-8.

\section{RECOMMENDATIONS}

There may be a need to organize regular workplace safety practices certification courses followed up with regular supervisory visits. This training could be incorporated into the apprenticeship process requiring certification before a trainee is granted permission by the regulatory body to be independent. Enacting laws and policy documents with possible sanctions where applicable could also help in ensuring compliance with workplace safety by these automobile mechanics in Surulere LGA, Lagos, Nigeria.

\section{ACKNOWLEDGEMENTS}

The authors are grateful to the Department of Community Health, Lagos University Teaching Hospital, Idi-Araba, Lagos State, Nigeria.

7. Rosenstock L, Cullen M, Fingerhut M. Occupational Health. Disease Control Priorities in Developing Countries. $2^{\text {nd }}$ edition . New York: oxford university press, 2006. 1127-30.

8. Public Information Department; Ministry of Information Culture Youth \& Sports; Lagos State (Nigeria). Our town series. 2007. p. 1-3.

9. Sabitu K, Iliyasu Z, Dauda MM. Awareness of occupational hazards and use of safety measures amongst welders in northern Nigeria. Ann Afr Med. 2009;8(1):46-51.

10. Omokhodion FO, Osungbade OO. Health problems of automobile mechanics in Nigeria. Tropical doctor. 1996; 26:102-4.

11. Sambo MN, Idris SH, Shamang A. Determinants of Occupational Health Hazards among Roadside Automobile Mechanics in Zaria, North-Western Nigeria. 2012;9(1):5-9.

12. Afolabi FJ, Beer P De, Haafkens JA. Occupational Risk Perception and the Use of Personal Protective Equipment (PPE): A Study Among Informal Automobile Artisans in Osun. SAGE Open. 2021; 11:1-10.

13. Oche $\mathrm{MO}$, Okafoagu $\mathrm{CN}$, Oladigbolu RA, Ismail $R$, Ango $T J$, Hashimu $A B$, et al. Determinants of Occupational Health Hazards among Roadside Automobile Mechanics in Sokoto Metropolis, Nigeria. Annals of African medicine. 2020;19(12):80-8.

14. Budhathoki SS, Singh SB, Sagtani RA. Awareness of occupational hazards and use of safety measures among welders: a cross-sectional study from eastern Nepal. BMJ Open. 2014;4(6):1-6. 
15. Kumar SG, Dharanipriya A, Kar SS. Awareness of occupational injuries and utilization of safety measures among welders in coastal South India. International Journal of Occupational and Environmental Medicine. 2013;4(4):152-172.

16. Eze BI, Okoye O, Aguwa EN. Awareness and Utilization of Welders' Personal Protective Eye Devices and Associated Factors: Findings and Lessons from a Nigerian Population. Workplace health \& safety. 2015;63(4):170-8.

17. Smith SM. Occupational Injuries, Illnesses, and Fatalities to Automotive Service Technicians and Mechanics, 2003 to 2005. 2007;1-5.

18. Johnson OE, Bassey EA. Work Habits and Health Problems of Automobile Technicians at Mechanic Village, Uyo, Nigeria. 2016;5(5):136-42.

19. Monney I, DwumfourAsare B, OwusuMensah I, Kuffour R. Occupational health, and safety practices among vehicle repair artisans in an urban area in Ghana. Journal of Environmental and Occupational Science. 2014;3(3):147-53.

20. Tagurum YO, Gwonson MD, Yakubu PM, Igbitar JA, Chingle MP, Chirdan OO. Awareness of occupational hazards and utilization of PPE amongst welders in Jos Metropolis Nigeria. Int J Res Med Sci. 2018;6(7):2227-33.

21. Aiyenigba BO. Effect of Health Education on the Knowledge and Safety practices of Auto Mechanics in Lagos State. National Post Graduate Medical of Nigeria; Fellowship Dissertation. 2005.

22. Khadka R, Pandey I, Gautam L. Occupational health hazards and use of personal protective equipment among auto mechanics in Kathmandu Metropolitan City, Nepal. International Journal of Occupational Safety and Health. 2021;11(1):16-24. 